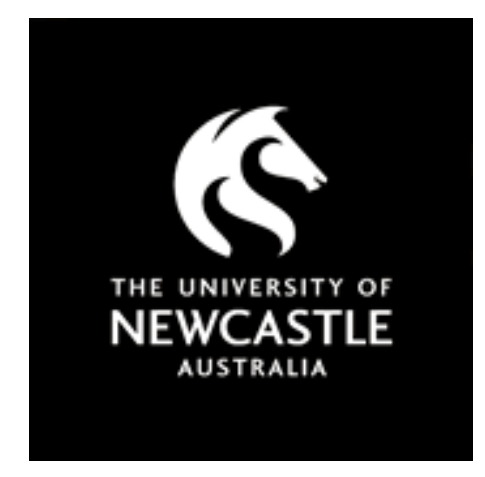

NOVA

University of Newcastle Research Online

nova.newcastle.edu.au

Wilden, Ralf; Gudergan, Siegfried; Lings, lan "Employer branding: strategic implications for staff recruitmentt", Journal of Marketing Management Vol. 26, Issue 1-2, p. 56-73 (2010)

Available from: http://dx.doi.org/10.1080/02672570903577091

This is an Accepted Manuscript of an article published in Asia Pacific Business Review on 31/03/2010, available online: http://www.tandfonline.com/10.1080/02672570903577091

Accessed from: $\underline{\text { http://hdl.handle.net/1959.13/1052262 }}$ 
Employer Branding: Strategic Implications for Staff Recruitment

\author{
${ }^{\text {a }}$ Ralf Wilden

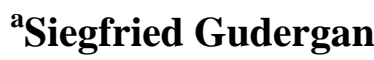 \\ ${ }^{\text {b}}$ Ian Lings

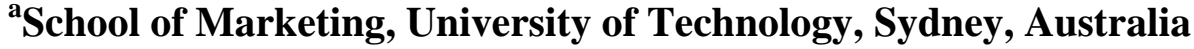 \\ PO Box 123 Broadway, NSW 2007 \\ bchool of Advertising, Marketing and Public Relations, Queensland University of \\ Technology, Brisbane, Australia \\ GPO Box 2434 Brisbane, Qld 4001
}

Author for Correspondence

Ralf Wilden

$\mathrm{T}: \quad+61-2-9514-9819$

F: $\quad+61-2-9514-9683$

E: ralf.wilden@uts.edu.au 


\title{
Employer Branding: Strategic Implications for Staff Recruitment
}

\begin{abstract}
In many developed economies, changing demographics and economic conditions have given rise to increasingly competitive labour markets, where competition for good employees is strong. Consequently, strategic investments in attracting suitably qualified and skilled employees are recommended. One such strategy is employer branding. Employer branding in the context of recruitment is the package of psychological, economic and functional benefits that potential employees associate with employment with a particular company. Knowledge of these perceptions can help organisations to create an attractive and competitive employer brand.

Utilising information economics and signalling theory, we examine the nature and consequences of employer branding. Depth interviews reveal that job seekers evaluate the attractiveness of employers based on any previous direct work experiences with the employer or in the sector; evaluations of the clarity, credibility, and consistency of the potential employers' brand signals; perceptions of the employers' brand investments; and perceptions of the employers' product or service brand portfolio.
\end{abstract}

Keywords - Employer Branding, Recruitment, Brand Equity, Signalling Theory, Qualitative Research

Ralf Wilden is a PhD candidate at the School of Marketing, University of Technology, Sydney. He earned his master's degree from the University of Munich specialising in strategic management and innovation management. His research interests include the topics of employer branding, marketing strategy, organisational performance as well as the dynamic capabilities view of firm strategy. Before enrolling in the doctoral program, he gained work experience in several industries while working for multinational organisations in the automotive, telecommunications, and consulting industries.

Siegfried Gudergan's research focuses on managerial and strategic decision making within organisations as it relates to employees who are working with customers; and managers who are working with internal and external business partners. Dr Gudergan is a Professor and Head of the School of Marketing, the Executive Director of the Centre for Management \& 
Organisation Studies (CMOS), and a researcher in the Centre for the Study of Choice (CenSoC). He completed his doctoral research at the Australian Graduate School of Management and was awarded a $\mathrm{PhD}$ degree in 2002 by both the University of Sydney and the University of New South Wales.

Ian Lings is Associate Professor in the School of Advertising, Marketing and PR at the Queensland University of Technology, Australia. He graduated from Nottingham Trent (UK) with a first in Applied Chemistry and, after working for Shell for several years, completed first an MBA and later a PhD at Aston University (UK). His research interests include service strategies, and the application of social and behavioural psychology to service delivery and consumption. Associate Professor Lings serves on several editorial boards and review panels and his work is published in a variety of journals including the Journal of Business Research, Journal of Service Research and Journal of Services Marketing. 


\section{INTRODUCTION}

With some regional differences, employment levels in many developed economies are very high, and competition for skilled staff is intense. Competitive labour markets aside, competition for employees is likely to become an increasingly important issue as the worldwide population ages. The proportion of the European population aged 15-60, from which most employees are drawn, is set to decrease from $62 \%$ to $49 \%$, and in North America will decline from $60 \%$ to $54 \%$ by 2050 (ABS 2006). In employment markets characterised by high competition, obtaining suitable human resources becomes increasingly problematic as the number of applicants per vacancy declines. Firms need to develop strategies to ensure that their human resource base remains adequate for the challenge of doing business. In increasingly competitive employment markets, developing strategies to become an employer of choice and increase the number of applicant per advertised vacancy can facilitate the recruitment of suitable employees and provides a strategic advantage to the firm. By adopting a resource-based view of the firm, the importance of human capital as a source of competitive advantage becomes apparent (Amit \& Schoemaker 1993; Hanson et al. 2002), and securing qualified staff becomes a strategic imperative. Following this logic, Branham (2001) suggest employer branding as a means of ensuring access to potential employees.

The employer brand is the package of psychological, economic, and functional benefits provided by employment and identified with an employer (Thorne 2004). Manipulating these benefits to position the firm in the minds of potential employees as a great place to work (an employer of choice) is the role of employer branding (Branham 2001). 
Closely related to employer branding is internal marketing which considers the company to act both on consumer and employee markets (e.g. Papasolomou-Doukakis 2003). The basic tenet of the internal marketing approach is that good customer service is only possible if employee satisfaction and motivation are high (e.g. Berry \& Parasuraman 1992). Consequently, internal marketing suggests that jobs are managed in a similar manner to products, and that the company should use marketing techniques to design jobs to meet both the employees' and the firm's needs, and to communicate the benefits of employment to internal and external markets. Creating a strong employer brand will have positive consequences for communicating these benefits.

Several scholars assert that brands and human capital constitute some of the firm's most important assets (Aaker 1991; Backhaus \& Tikoo 2004) and that the development of these intangible assets is an important task for marketers and human resource managers (Sutherland, Torricelli \& Karg 2002). The human capital involved in the design and offering of products in general, and the delivery of services in particular, influences perceptions of the firms' consumer brand in the market (e.g. Papasolomou-Doukakis 2003). Simultaneously, the firm's consumer and employer brands affect how existing and potential employees perceive the firm.

Whilst much attention has been dedicated to examining the role of branding from a customer perspective and associated customer-based brand equity (e.g. Taylor, Hunter and Lindberg 2007), relatively little research has explored the role that branding plays in retaining and attracting employees that constitute the firm's human capital and, ultimately, contribute to the efficient and effective delivery of products and services. This paper addresses this research gap and focuses on developing a better understanding of the role that branding plays in 
attracting human capital to the firm as this is the stage when employee expectations are set; more specifically, we adapt and test a modified consumer based brand equity model in the context of employment markets and present a new conceptualisation of employee-based brand equity.

To achieve this, the paper is organised as follows. In section 2 we present a review of extant literature in cognitive psychology and signalling theory relevant to brand equity. In this section, we analyse the employment market from a signalling perspective. In section 3 , we synthesise this literature and develop a conceptual framework to explain employee-based brand equity. Based on this conceptualisation several propositions are derived. In sections 4 and 5, we discuss our research approach and present the findings of preliminary, qualitative research. Finally, in section 6, we conclude the paper with a discussion of the implications of our study and directions for further research.

\section{BRANDS AND EMPLOYEES}

Most common brand definitions focus on customers and not on other stakeholders, such as potential employees, who are also influenced by brand messages. A brand is "essentially $a$ seller's promise to consistently deliver a specific set of features, benefits and services to the buyers [and ...] is intended to identify the goods and services of one seller [...] and differentiate them from those of competitors (Kotler 1997, p. 443)“. However, in the context of employer marketing, the employer brand is to be understood as the set of distinctive images of a prospective employer which are manifest in the minds of the target groups- potential employees (Meffert, Burmann \& Koers 2002; Petkovic 2004). The difficult task for any organisation is to manage the multiple brands it presents to its various stakeholders (e.g. 
consumer brands, company brand, employer brand). Important in this context is the link between the human resource management function and marketing (see Martin et al. 2005). Both marketers and HR specialists need to be aware of the impact of their actions on each other's branding objectives, and as much as possible, need to align their efforts. The employer brand is affected by, and may affect, all of the other brands of the firm, and aligning internal belief about the firm and external brand messages is paramount. Companies with product brands with low consumer awareness may find it harder to attract highly skilled human capital, as potential recruits are less aware of the employer. Similarly, if product brands are seen as unattractive in consumer markets, potential recruits may have negative associations with the company and so may be reluctant to consider employment with the organisation.

\section{Brand Equity and Signalling}

The marketing discourse has predominantly focused on the impact of product or corporate brands on consumers' attitudes, and their consequences for brand equity (e.g. Keller 1993; Swait et al. 1993). Tsao (2002) suggests two means of measuring brand equity; the first, derived from cognitive psychology; the second, from information economics. Cognitive psychology suggests that buyer-based brand equity is a consequence of the performance and personality of the brand and is reflected in the perceptions of buyers (Tsao 2002). Keller (1993, p. 1) states that "Customer-based brand equity is defined as the differential effect of brand knowledge on consumer response to the marketing of the brand." Brand knowledge provides important benefits to consumers by facilitating their information processing, increasing confidence in their brand choices, reducing perceived risk and information costs. Consequently, brand equity is reflected in changes in consumers' perceptions of risk, confidence and information costs. Previous research on human resource management has 
discovered the value of investigating recruiting from a marketing perspective and used the cognitive psychology approach to brand equity. Collins \& Stevens (2002, p. 1132) found that “exposure to early recruitment activities was positively related to job seekers' attitudes and perceived attributes. Further, these elements of brand image were significantly related to application intentions and actual decisions.”

The cognitive psychology view of brand equity is based on an assumption of knowledge in the marketplace; i.e. the individual has access to information about the brand. This view does not explicitly account for the information asymmetries inherent in these market interactions (Erdem \& Swait 1998). Information economics overcomes this limitation by accounting for interactions among the involved parties, and recognising problems that arise from asymmetric information in the market (Spence 1973). In employment markets, asymmetric information motivates the information seeker to search for information in order to overcome the perceived information gap; consequently information costs may be incurred. The roots of this approach stem from the work of Vickrey (1961), Mirrlees (1971), Akerlof (1970) and Spence (1973) in signalling theory. This theory suggests that in order to avoid adverse selection, information seekers use signals such as warranties, price, and brands to formulate their quality judgements (e.g. Dawar \& Parker 1994; Koku 1995). In the context of branding, Kirmani and Rao (2000) suggest that brands are sale-independent signals; they communicate unobservable quality, regardless of a transaction (Erdem \& Swait 1998). Information asymmetry and signalling theory have potential applications in employment markets as would-be employees rarely have perfect information about a prospective employer. Employment with a particular firm will have long-term implications for employees (and employers) and these consequences motivate potential employees to invest effort into gaining information about prospective employers. 
Sending appropriate signals, via employer branding, is one means that prospective employers can reduce potential employees’ information costs associated with this search.

In summary, despite increasing competition in employment markets, little research has explored the mechanisms by which potential employees evaluate prospective employers, and the employee-based brand equity inherent in these evaluations (Ewing et al. 2002; Schmidtke 2002; Sutherland, Torricelli \& Karg 2002). Knowledge gained through research examining customer-based brand equity may provide a framework to better understand how to develop an employer brand that communicates messages to potential employees about the quality of an organisation as an employer. In particular, signalling theory provides insights into branding and brand signals that can be used to develop and communicate this quality message to employment markets.

\section{The Job Market Mechanism}

The job market is characterised by information asymmetry. Prior to commencing a job, and directly experiencing work conditions first hand, a potential employee cannot fully assess the quality of a prospective employer with certainty. The same is true from the employer's perspective (Spence 1974). Given the importance of employment contracts, and their long term implications for both the employee and the employer, both parties are motivated to identify ways to reduce this information asymmetry and lessen the problem of adverse selection. From the potential employees' perspective, asymmetric information arises from the unobserved characteristics of the prospective employer, e.g. work climate and career development, etc (Schmidtke 2002). Given the risk to both parties, it is in the best interest of a potential employee to find out as much as they can about a prospective employer, and for a 
prospective employer to signal to the employment market, their competencies and characteristics (Spence 1974, p. 1). Characteristics inherent in the firm's brand influence potential employees' understanding of the firm as a prospective employer. If the potential employee has insufficient, inconsistent or incorrect beliefs about a prospective employer, potential employees may perceive high risks associated with joining the organisation and, consequently remove them from their consideration set of prospective employers; selecting an alternative employer for which they perceive less risk.

Though the focus of this paper is to investigate the role of employer branding to potential employees, it is not restricted to this context. Existing employees also receive signals from the organisation about their suitability as an employer. Such brand signals are also likely to have an impact on the attitudes of existing employees (although these attitudes will also be formed via direct experience). The impact of employer branding on both potential and existing employees is articulated by Dell et al. (2001, p. 10) who assert that "the employer brand establishes the identity of the firm as an employer. It encompasses the firm's values, systems, policies, and behaviours toward the objectives of attracting, motivating and retaining the firm's current and potential employees". This suggests that firms can overcome uncertainties and risk experienced by potential and existing employees, by purposefully designing an employer brand aimed at the employee market.

The extent to which the brand contributes to retaining and attracting employees constitutes the equity associated with the employer brand. This employee-based brand equity is increasingly recognised by financial markets, and increasingly human capital constitutes part of the market value of an organisation (Cairncross 2000). In the employee context, brand equity can be 
defined as "the effect of brand knowledge on potential and existing employees of the firm." (Backhaus \& Tikoo 2004).”

\section{Conceptual Framework for Employee-Based Brand Equity}

Based on signalling theory and information asymmetry, we present a framework in which the potential employee is the uninformed party and is uncertain about the quality of employment with the prospective employer.

Utilising a similar logic to Spence's job market model (1974), we view the employer brand as a signal to overcome this information asymmetry and to affect employee-based brand equity. We present a conceptual framework for employee-based brand equity, modified from previous consumer based branding research examining the role of brand signals on consumers evaluations of product quality (Erdem et al. 1999). The employee based brand equity framework is presented in Figure 1.

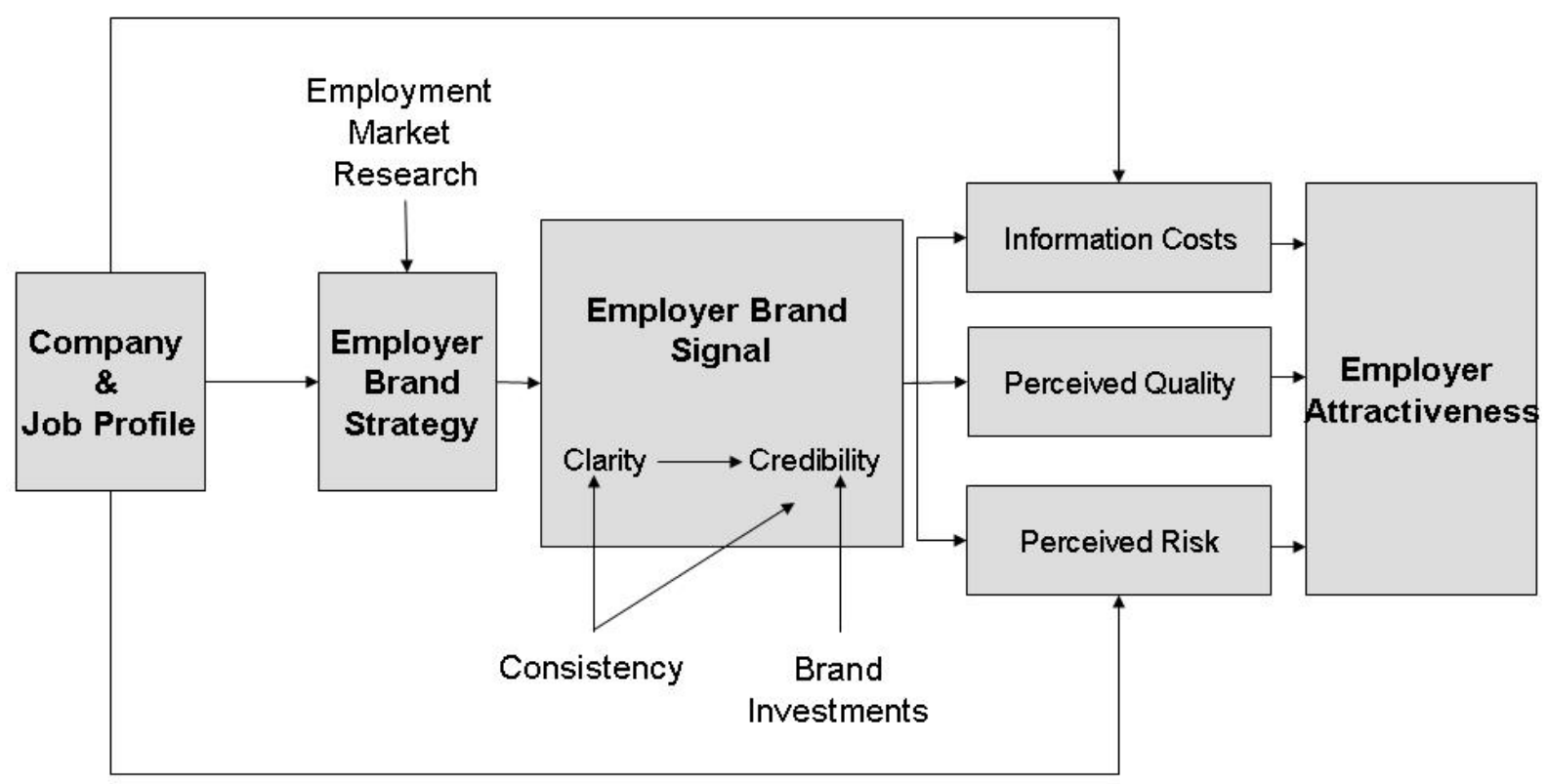

Figure 1: Conceptual Framework of Employee-Based Brand Equity (modified from Erdem and Swait (1998)) 
If one adopts the internal marketing view, that employment opportunities (jobs) are one of the products offered by the firm (e.g. Sasser \& Arbeit 1976), models of consumer behaviour may be applied to the employment market. In the same way that market information, prior experience and trust in the brand influence product evaluations; job evaluations may be influenced by search, experience, and trust characteristics (Franck, Pudack \& Opitz 2001; Schmidtke 2002; Teufer 1999). Potential employees can directly observe certain characteristics of a job, such as location and salary. However, other characteristics, such as work climate and employee orientation within the company cannot normally be observed by potential employees ex ante. In assessing the attractiveness of a prospective employer, potential employees incur costs associated with seeking the information necessary to make an informed decision. They may search for observable information directly and/or make use of information substitutes. Searching for observable information is only possible for search characteristics such as location and salary; for experience and trust characteristics (e.g. career development, performance-based remuneration, and work climate) the potential employee needs to make use of information substitutes such as brand signals (Weiber \& Adler 1995).

To ensure that these brand signals convey the desired message to the employee market, companies must dedicate effort to their employer branding strategies. Employer branding affects the company profile by sending employer brand signals to recruitment markets. These employer brand signals reduce potential employee's information costs, and influence their perceptions of job quality, and the risk associated with joining the company. These signals create expected utility for potential employees, which can also be defined as employer attractiveness, an important element of employee-based brand equity. Employer attractiveness is the set of "envisioned benefits that a potential employee sees in working for a specific organisation"(Berthon, Ewing \& Hah 2005). 
Applying utility theory in the context of branding (Meffert, Burmann \& Koers 2002) to the job market, provides a basis for viewing the employer brand as a signal that has the potential to create utility for both the prospective employer and potential employee. From the perspective of the potential employee the employer brand serves several functions. It provides orientation during the selection process as strong employer brands give rise to a position of 'Employer of Choice', and serves as a quality indicator to the employment market. Consequently potential employees consider statements given by such companies to be more trustworthy. Furthermore, once having joined the organisation, the brand can serve as a mechanism to help employees to identify with the employer; working for a prestigious company makes employees proud and may result in higher work morale. For the prospective employer, the employer brand can increase the perceived value of the company as an employer, enabling segment specific recruitment strategies to be developed, supporting employee retention, differentiating the firm from other employers, and affecting preferences for other employers in the job market. In order to achieve this, employers must invest in clear and consistent brand signals to ensure that their position as 'employer of choice' is understood by potential employees.

Following Erdem and Swait (1998), we assert that the clarity of a brand signal is determined by unambiguous information conveyed by the employer's brand. Clear communication of the employer brand and absence of bias in brand signals gives rise to a credible position in the employment market. Clear brand signals also reduce information costs for potential employees; when employees receive a believable, distinct image of the company as a prospective employer, they do not need to invest as many resources into unpacking and interpreting brand messages. This reduction in information costs leads prospective employees 
to perceive less risk associated with joining a company and higher employment quality. This gives rise to the following propositions:

$\mathrm{P}_{1 \mathrm{a}}$ : $\quad$ Greater brand clarity leads to increased credibility of the employer’s brand message.

$\mathrm{P}_{1 \mathrm{~b}}$ : Greater brand clarity leads to lower perceived risk associated with the employer.

$\mathrm{P}_{1 \mathrm{c}}$ : $\quad$ Greater brand clarity leads to lower information costs associated with gathering information about the employer.

$\mathrm{P}_{1 \mathrm{~d}}: \quad$ Greater brand clarity leads to increased perceived quality of the employer.

Credible brand signals convey information which has greater potential to be effective in reaching the target group (Tirole 1990). Potential employees' perceptions of the credibility of the employer brand signal is dependent on their evaluation of the trustworthiness of the prospective employer (Hoeffler \& Keller 2002), and potential employees' perceptions of the willingness and ability of the prospective employer to deliver what is promised (Erdem \& Swait 1998). Promises made to potential employees during recruitment affect their expectations and subsequent evaluations of the job (Buss 2002). Unfulfilled expectations may lead to employee dissatisfaction and turnover. Additionally, negative word of mouth may result and employee referrals may decrease, (Miles \& Mangold 2004). If a signal is credible and the prospective employer is considered trustworthy, potential employees associate decreased risk with employment by the firm, and gain comfort from the expectation that promises made by the company are likely to be fulfilled. This, ultimately, increases their perceptions of the quality of the firm as a prospective employer. Consequently, potential employees reduce their efforts to gain additional information about the prospective employer, reducing their information costs (Erdem \& Swait 2004).

$\mathrm{P}_{2 \mathrm{a}}$ : $\quad$ Greater brand credibility leads to decreased perceived risk regarding the employer. 
$\mathrm{P}_{2 \mathrm{~b}}$ : $\quad$ Greater brand credibility leads to decreased information costs regarding the employer.

$\mathrm{P}_{2 c}$ : $\quad$ Greater brand credibility leads to increased perceived quality regarding the employer.

Brand consistency has both substantial and temporal dimensions. The substantial dimension of brand consistency refers to the degree to which each employer brand signal reflects the intended whole (Buss 2002; Erdem \& Swait 1998), and the degree to which these signals are aligned with the overall objectives of the firm and associated product and corporate brands (Backhaus \& Tikoo 2004; Mitchell 2002). The temporal dimension of employer brand consistency reflects the extent to which employer brand signals are consistent over time (Park, Jaworski \& Maclnnis 1986). Higher consistency in brand signals alleviates confusion and associated information costs for the potential employee's; consequently reducing the risk associated with taking employment. Finally, consistent brand signals give rise to perceptions of higher credibility of the prospective employer (Erdem \& Swait 1998, 2004).

$\mathrm{P}_{3 \mathrm{a}}: \quad$ Greater consistency leads to reduced perceived risk regarding the employer.

$\mathrm{P}_{3 \mathrm{~b}}$ : $\quad$ Greater consistency leads to decreased information costs regarding the employer.

$\mathrm{P}_{3 \mathrm{c}}: \quad$ Greater consistency leads to higher employer brand credibility.

The credibility of employer brand signals is likely to be dependent on the level of investment that the organisation makes in its employer brand (Dawar 1998). Typically, organisations adjust their signalling budget according to importance of the position on offer. Higher brand investments motivate the company to be truthful in their claims about the job offer and demonstrate commitment (Erdem \& Swait 1998; Kirmani \& Rao 2000). 
$\mathrm{P}_{4 \mathrm{a}}$ : $\quad$ Greater brand investment is associated with greater employer brand credibility.

Ultimately, employer branding efforts aim to communicate the expected utility that a potential employee should anticipate from joining a company, and so build employee-based brand equity. This can also be described as employer attractiveness (Berthon, Ewing \& Hah 2005). If potential employees have to commit high levels of resources in order to gain insights into a company, they may associate higher risk with joining the company and perceive the company as a less attractive prospective employer. If the information gained via signals is promising, perceived risk is reduced and the anticipated quality of a job enhanced. Consequently, potential employees will perceive the employer as more attractive (Aaker 1991).

\footnotetext{
$\mathrm{P}_{5 \mathrm{a}}: \quad$ Information costs decrease employer attractiveness.

$\mathrm{P}_{5 \mathrm{~b}}$ : $\quad$ Perceived quality of the job increases employer attractiveness.

$\mathrm{P}_{5 \mathrm{c}}$ : $\quad$ Perceived risk decreases employer attractiveness.
}

\section{METHODOLOGY}

In order to gain additional insights into the conceptual framework and to further clarify the concepts and effects anticipated from the literature, preliminary research, in the form of semi-structured, indepth interviews, was undertaken. Respondents were chosen from potential employees who were currently actively searching job positions. This sample has been chosen as it was expected that the concepts contained within the framework would be particularly salient in this context. In depth interviews were conducted to provide detailed insights into the nature and role of each concept, and to assist in the development of an empirically relevant framework. 
In total, 30 in-depth interviews were undertaken with job seekers. Respondents were recruited through a referral based convenience sample utilising a snowballing technique. Job seekers were chosen as they are engaged in the recruitment process, allowing them to provide informed comments on the topic at hand. In order to maximise the richness of the insights generated from interviews, respondents were chosen from a range of cultural backgrounds (Australia, Germany, India, Canada, and Singapore), different educational backgrounds and were of varied age. All but five of the respondents have held previous full-time work positions and were seeking for either a new job or a career change.

Interviews were conducted based on a theory derived interview guide in a semi-structured format as recommended by (Lee 1999). During the interviews, respondents were asked to discuss the following topic areas: 1) previous experiences with employers and future career planning; 2) process of employer image creation; and 3) employment selection criteria. Following the recommendation of Patton (1990), respondents were not given pre-determined categories of responses or topics to be covered. This minimises interviewer bias and maximises information regarding the empirical relevance of the constructs included in the study.

All interviews were audio recorded and transcribed in full. The transcripts were analysed following typical qualitative procedures (e.g. Glaser \& Strauss 1967; Strauss \& Corbin 1998). Following the recommendations of (De Chernatony \& Cottam 2006), phenomena within each of the interviews were compared with incidents from other interviews and with insights gained from the literature. This resulted in a comprehensive categorisation of the concepts and their roles evident in the data. 


\section{RESULTS AND IMPLICATIONS}

Brand Clarity and its relationships

Analysis of the interviews reveals that potential employees associate clear brand signals with having to invest less effort into gaining information about a prospective employer (support of $\mathrm{P}_{1 \mathrm{a}}$ ). Respondents mentioned that in most cases with bigger firms the brand values and propositions of the overall company are rather clear but the job descriptions and the specific employer brand values are rather ambiguous and unclear. This led one recruit to attend a job interview without knowing the specifics of the actual job and the HR staff from that company did not help much to reduce that ambiguity. Consequently the potential recruit had to search for further information to reduce this uncertainty; as a result higher search costs occurred, mainly in the form of psychological stress and additional time invested.

Regarding the depth of employer brand information, the interviewees were consistent in their opinion that, in general, all companies provide too little information regarding employment. However, opinions regarding if this is a bad thing or not differed widely. Some respondents see this lack of information as an opportunity for them to perform better than other candidates, as they consider their ability to search for additional information to provide them with “an edge”. Some respondents saw higher levels of information regarding a prospective employer as potentially detrimental to their interview performance. For example, one interviewee stated that they would not like to get more information regarding a prospective employer, as they would need to memorise everything when attending a job interview. 
Within the context of brand clarity and brand consistency, we find that the experience of potential employees influences their opinions. Respondents with more experience of the workplace were more reflective and critical in their evaluations of prospective employer brand signals. One interviewee describes his process of employer selection over time as follows:

“I think ... [with your] first job, you are not as [...] critical in your assessment, [I was] attracted by the major $[\ldots]$ product brand name. The role was [...] a junior role, but I took it mainly because it is a big brand name. [...] When I look back at [my second employer], there was some sort of indication that I shouldn't have gone there in terms of a [mess] up in the recruitment process, my confidentiality was destroyed when they were going through the work places. [...] But at the same time, it had the same sort of attraction to me because of the big brand name. [...] Because of that experience though, the next time I was much more careful, it was a much more measured interview process.” (Australian male, 30, employee, eight years of work experience with four different employers)

Work experience also appeared to influence the utility that respondents anticipated from longer term aspects associated with career development. More experienced respondents were likely to value a specific company's contribution to their career profile and the chances for promotion, whilst less experienced respondents expressed greater utility from short-term phenomena such as income. It appears that factors such as career development and work culture have greater salience for more experienced potential employees, than those just entering the workforce.

One of the main driving forces for inexperienced respondents is to have a strong corporate brand on their $\mathrm{CV}$; other important factors for this group are training and mentorship. Monetary benefits are important to both groups, but no interviewee counts salary as the single 
most important reason for prospective employer selection, though inexperienced employees lay more importance on this. This would suggest that increasing employee-based brand equity requires that companies should create an employer brand image that promotes a strong commitment towards learning and development rather than just stressing salary.

Analysis of the transcripts also revealed that all respondents experienced risk associated with potential employment scenarios. Interestingly, the majority of respondents did not identify risk associated with the prospective employer failing to deliver on their promises; rather they were more concerned with the risk that they would underperform, relative to the expectations of the prospective employer. Higher clarity of what is expected leads to lower perceived risk of joining the company (support of $\mathrm{P}_{1 \mathrm{~b}}$ ). One explanation for this finding may be that, although employment levels are currently high, and competition for employees is strong, this is of little comfort for potential employees currently seeking employment. They appear to be more concerned about being clear of what is expected of them and demonstrating their worth and good performance, rather than understanding the promises that are being made to them and evaluating prospective employers for the most favourable conditions of employment. Psychological contracting (Rousseau 2003; Rousseau \& Greller 1994; Rousseau \& WadeBenzoni 1994) provides some insights into the role of risk in employment decisions. The psychological contract implies that both prospective employer and potential employee create mutual expectations during the recruitment stage. Therefore, an employer brand image which causes a mismatch between expectations and reality can lead to workers' dissatisfaction and eventually decreased employee retention. It is important that companies set appropriate brand statements which clearly communicate employment values and expectations to applicants. According to the respondents, clear brand signals lead to clearer brand images in the potential 
employee's mind and reduce the perceived risk of joining a company which ultimately increases employer attractiveness (support of $\mathrm{P}_{5 c}$ ).

Brand Credibility and its relationships

Jobs, when viewed as products, combine search, experience, and trust characteristics. Research in consumer theory has shown that the credibility of experience claims can be increased when the claim is stated by a highly credible source (Jain \& Posavac 2001). From our respondents' point of view, prospective employers generally provide low credibility signals to the employment market. Respondents indicated that personal relationships are one way that they gain credible employer brand signals; with many respondents making use of these personal networks prior to deciding to join a company in order to reduce their perceived risk of joining the company (support of $\mathrm{P}_{2 \mathrm{a}}$ and $\mathrm{P}_{2 \mathrm{c}}$ ). Respondents viewed employee referrals as the most credible and trustworthy of information sources (see also Collins \& Stevens 2002). We conclude from this that credibility has a positive effect on the likelihood of joining a company and ultimately increases the employee-based brand equity of the company. The relationship between employer brand credibility and the perceived quality of the firm as a prospective employer is only relevant if a company is already in the consideration set of a potential employee. Credibility alone will not increase employee-based brand equity. Consequently, we recommend that companies utilise credible brand ambassadors so that relevant brand messages are communicated to employment markets. Current employees are seen as credible ambassadors for the firm to the recruitment market (presumably as they have no transparent vested interest). Our findings also suggest that recruitment agencies are not be seen as credible ambassadors to the market. Although not all respondents had first hand experience with recruitment agencies, the few who had, agreed that they did not credibly 
convey the employer brand of the potential employer. One interviewee openly criticised the common practice of using recruitment agencies and brand disguised adverts when recruiting.

\begin{abstract}
“[...] When I see an ad in the newspaper or on the web and they don't reveal the brand name, I hate that. You know, you should be proud of your brand [...] Some companies don't advertise their brand as they are going through an agency. For whatever reason they choose not to give their brand [...], but for me, I like to know who I am going to work for.” (Australian male, 28, employee, seven years of work experience with one company, recently started a new job with different company)
\end{abstract}

Although there may be important considerations for the firm leading to a decision to disguise its identity in recruitment adverts, this action may have long-lasting detrimental effect on an employer's brand credibility. Companies that initially disguise their true identity (for whatever reason) may be seen to not be proud of their brand. This fact has negative repercussions on the employer brand equity as the credibility of the employer brand may be diminished.

Respondents also identified a relationship between employer brand investments and employer brand credibility. Interviewees named several examples which they interpret as investments into the employer brand. These include devoting resources to employee development, participating in career fairs, maintaining career websites, advertising in business magazines, offering internships as well as being active in alumni networks and participating in employer of choice awards. We find that high investments into creating employer brand awareness among potential and existing employees, and investments into human resource measures, create a perception that the employer cares about its workers. Many respondents suggested that higher brand investments imply that a company would be more desirable to work for. One explanation for this observation may be that higher investments in the employer brand 
increase the credibility of brand signals conveying the importance of employees to the firm, ultimately giving rise to perceptions of quality, employer attractiveness, and employee based brand equity (support of $\mathrm{P}_{5 b}$ ).

Our respondents also identified differing brand investments across industries. The respondents generally agreed that accounting firms and consultancies have very professional recruitment processes, whereas advertising agencies appear to dedicate too few resources to recruitment, making it difficult for potential employees to get to know them. Companies that dedicate more resources to recruiting and employer brand building are perceived as being a more attractive place to work than companies that do not. Accordingly, we find some support for the proposition that brand investments positively influence perceived job quality.

\section{Brand Consistency and its relationships}

The interviews showed that two types of consistency are relevant to the potential employees. The first refers to the extent to which the information a company provides regarding employment is consistent across messages, the second refers to the extent to which the product brands are in harmony with the employer brand. Respondents mentioned that inconsistency between the recruitment information provided and the associated product or service brand signal would decrease their trust in the prospective employer's signals, ultimately decreasing prospective employer brand credibility (support of $\mathrm{P}_{3 c}$ ). This is also closely related to the relationship between consistency and information costs: If potential employees face contradicting and inconsistent information about a prospective employer, they are required to dedicate more resources to searching for additional insights about the company; this increases their information costs (support of $\mathrm{P}_{3 \mathrm{~b}}$ ). As one interviewee states: 
"Little consistency would lead me to trust the company less. [...] Higher consistency leads me to search less for information as no ambiguity exists.” (German male, 31, student, eight years of work experience with five different employers)

We find that the extent to which a product brand matches the employer brand is an important determinant of employee-based brand equity. Most interviewees supported the rationale that the corporate and the product brands have a significant influence on how they (as a potential employee) perceive the company as a prospective employer. As one interviewee states:

\footnotetext{
"My favourite industry is the one of fast moving consumer goods. And [Company X] is one of the top players in that industry. So I always [...] want[ed] to work for them, because they are very innovative and offer great products. But through contacts and further information I found out that the working environment is not as positive, not as creative as I had expected.” (German male, 26, graduate student, two years of work experience)
}

We conclude from this that companies need to be consistent in their statements regarding employment, and to seek alignment between the various brands that the company offers. Mitchell (2002) states that the employer brand should not be treated independently from the corporate brand and associated strategy. This is particularly important in creating an opinion about the firm as a prospective employer. Potential employees with little work experience emphasise the importance of product brands in forming an opinion about a firm as prospective employer.

\section{Further Findings}

Most of our respondents expressed clear ideas regarding their preferred industry, but struggled naming an employer they would like to work for. Respondents expressed a 
preference for working in an industry, either based on the products offered (e.g. fast moving consumer goods, airline industry) or by preferred task (e.g. accounting, advertising). It appears, at least from our respondents, that the industry in which a company is embedded has a stronger influence on potential employees than the employee based brand equity or company brand.

\footnotetext{
“[Companies from other industries] couldn’t have done much as I was totally focused on that one [auditing] industry. There wouldn't have been a great chance that a company could have put me into the distribution or supply, [this] was not really an option. [...] As I wanted to work in the industry it was not that important to me in which company I could start working, in a bigger company with a strong reputation or in a smaller one. The work...the activities of an auditor were more decisive for me than a company.” (German male, 25, employee, two years of work experience)
}

This fact becomes even more relevant as many potential employees apply for positions through recruitment agencies and, therefore, often do not deal directly with employer brand signals, particularly in the early stages of the decision process. This suggests that potential employees often only state their interest in the selected industries that the recruitment agencies represent. This is similar to the situation of consumers wishing to purchase from a product category but having little awareness of competing brands within that category.

Implications of findings

Our empirical findings suggest that the original framework derived from consumer goods brand equity theory provides a suitable basis from which to conceptualise employee-based brand equity. However, the consumer-based framework requires modification to the employee context. 
Our respondents generally expressed an opinion that they would like to receive more information about prospective employers, but the amount of effort they have to put into finding additional information does not seem to have a significant effect on the prospective employer attractiveness. Potential employees are prepared and willing to search for information in addition to that which is provided by the employer brand. This may be due to the high importance of the decision for one's future career; additional empirical research may reveal the relative importance of information costs in this process.

Furthermore, the product brands of a prospective employer appear to influence the decision making process of potential employees and, thus, a company’s employee-based brand equity. This suggests a need for alignment of the employer, company and product brands of an organisation. This is especially important when recruiting less experienced potential employees as a consumer brand often is the only, or a dominating, signal that they receive from a prospective employer.

The consumer-based brand equity framework presented by Erdem and Swait (1998) and modified in this study, does not explicitly address the role of previous experience in the creation of brand equity. Our findings suggest that this has a significant influence on how potential employees perceive employer brand signals. Respondents with more work experience were more critical in their assessment of the clarity and credibility of the employer brand; they were more cynical. This may also provide insights into which brand signals may be more effective for different target groups. When targeting experienced employees a company ought to be clearer and more consistent in their employer brand signals, as these potential employees are influenced less by the consumer brand signals the company sends. 
Potential employees with less work experience appear to be more influenced by consumer brand signals and dedicate less effort to interpreting employer brand signals less as they are also less able to do so.

Finally, we find that most of our respondents' decide first which industry they want to work in. Therefore, the industry in which a prospective employer is embedded influences its membership in the potential employee's consideration set of prospective employers. Other decisions such as location and company size also influence membership of this consideration set.

In summary, employee-based brand equity is influenced by employer brand clarity, consistency, brand investments and the credibility of brand signals; factors that a company may control given sufficient motivation. However, other factors such as the potential employee's previous work experience, the industry in which a company is embedded, location and company size also influence the value that a potential employee places on a prospective employer, and consequently their employee-based brand equity. Our findings also suggest that information costs have a significant influence on employee-based brand equity, implying that recruiting organisations should invest in making information available to potential employees. Finally, brand investments appear to influence the attractiveness of a prospective employer and consequently its employee based brand equity. In line with our findings we propose a modified conceptual framework in Figure 2. 


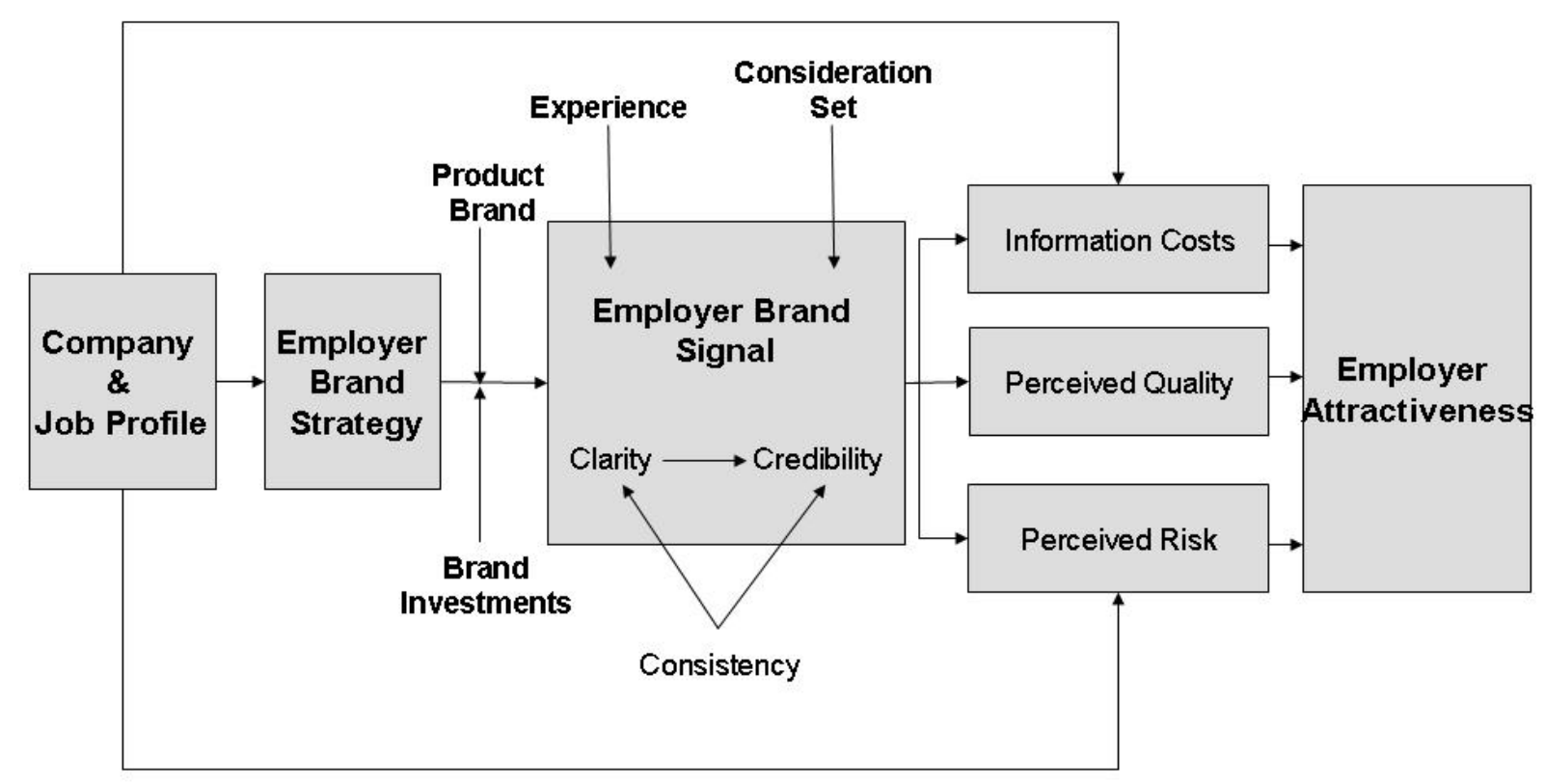

Figure 2: Revised Conceptual Framework for Employee-Based Brand Equity

\section{CONCLUSION AND FURTHER RESEARCH}

The findings of our research are relevant to both marketing managers and academics as the search, and competition, for talented employees requires organisations to invest resources in employment related branding strategies. This paper proposes a conceptual framework for employee-based brand equity. This framework suggests that the effectiveness of a brand signal to potential employees is dependent on the consistency, clarity, credibility, and associated investments in the employer brand. Furthermore, for an employer brand signal to have an effect on a potential employee's decision making process the company has to be in the consideration set of the potential employee, membership of which is often determined by the industry in which the firm is embedded or location where the firm is based. Prospective employers should also consider the work history of potential employees when developing their employer branding strategies. Previous experience is found to influence the credence that potential employees' place on the employer and customer brands of the firm. Consequently 
employers should differentiate their marketing and HR efforts according to the work experience of the potential recruits, focus their recruitment investments on target markets that consider working in the relevant industry as well as make sure to align the different brand messages that are sent out by different departments of the company. Furthermore, word-ofmouth through referrals appears to be the most credible source of employer brand information and mangers should make use of this fact and establish employee referral programs.

Several limitations constrain the generalisability of the findings and provide opportunities for further research. First, the sample only included employees seeking a new job or a career change. Whilst this is appropriate for testing our framework as it aims to explain the role of employer branding in recruitment markets and the impact of employee-based brand equity on the ability of the firm to attract scarce human resources, both theory and our qualitative interviews highlight the relationship between employer branding and employee retention. Psychological contract theory may provide insights into how mutual expectations between the prospective employer and the potential employee develop, and how employer brand signals may influence the human capital life cycle, both pre- and post-recruitment. Further research should therefore explore the role of the employer brand in employee retention and its possible implications for customer attraction, satisfaction and retention (see for example Cardy, Miller and Ellis 2007). Further empirical research is needed to explore and quantify the relationships between the concepts in the nomological framework presented in our modified conceptual model.

Second, the presented conceptual framework focuses on brand equity from a potential employees’ perspective. Further research should also explore the extent to which employeebased brand equity is part of a wider framework of brand equity, synthesising existing 
conceptualisations of customer-based brand equity and employee based brand equity, and possibly developing and integrating brand equity associated with other stakeholder, such as investors and community. 


\section{REFERENCES}

Aaker, D. (1991), Managing Brand Equity, New York: The Free Press.

Akerlof, G. (1970), "The Market for 'Lemons': Qualitative Uncertainty and the Market Mechanism", Quarterly Journal of Economics, Vol. 84, No. 3, pp. 488-500.

Amit, R. \& Schoemaker, P.J.H. (1993), "Strategic assets and organizational rent", Strategic Management Journal, Vol. 14, No. 1, p. 33.

Australian Bureau of Statistics, A. (2006), Population Projections, Canberra: Australian Bureau of Statistics.

Backhaus, K. \& Tikoo, S. (2004), "Conceptualizing and researching employer branding", Career Development International, Vol. 9, No. 4/5, pp. 501-517.

Berry, L. \& Parasuraman, A. (1992), "Services Marketing Starts From Within", Marketing Management, Vol. 1, No. 1, pp. 24-34.

Berthon, P., Ewing, M. \& Hah, L.L. (2005), "Captivating company: dimensions of attractiveness in employer branding", International Journal of Advertising, Vol. 24, No. 2, pp. 151-172.

Branham, L. (2001), Keeping the people who keep you in business: 24 ways to hang on to your most valuable talent, New York: American Management Association.

Buss, D. (2002), "In good company", Brandweek, Vol. 43, No. 20, pp. 28-34.

Cairncross, F. (2000), "Survey: E-management--Inside the machine", The Economist, Vol. 357, No. 8196, p. S5.

Collins, C.J. \& Stevens, C.K. (2002), "The Relationship Between Early Recruitment-Related Activities and the Application Decisions of New Labor-Market Entrants: A Brand Equity Approach to Recuitment", Journal of Applied Psychology, Vol. 87, No. 6, pp. 1121-1133.

Dawar, N. (1998), "Product-Harm Crises and the Signaling Ability of Brands", International Studies of Management \& Organization, Vol. 28, No. 3, pp. 109-119.

Dawar, N. \& Parker, P. (1994), "Marketing universals: Consumers' use of brand name, price, physical appearance, and retailer", Journal of Marketing, Vol. 58, No. 2, pp. 81-95.

De Chernatony, L. \& Cottam, S. (2006), "Internal Brand Factors Driving Successful Financial Services Brands", European Journal of Marketing, Vol. 40, No. 5/6, pp. 611-633.

Dell, D., Ainspan, N., T., B., Troy, K. \& Hickey, J. (2001), Engaging Employees Through Your Brand, Research Report 1288-01-RR, New York. 
Erdem, T. \& Swait, J. (1998), "Brand Equity as a Signaling Phenomenon", Journal of Consumer Psychology, Vol. 7, No. 2, pp. 131-157.

Erdem, T. \& Swait, J. (2004), "Brand Credibility, Brand Consideration, and Choice", Journal of Consumer Research, Vol. 31, No. 1, p. 191.

Erdem, T., Swait, J., Broniarczyk, S., Chakravarti, D., Kapferer, J.-N., Keane, M., Roberts, J., Steenkamp, J.-B.E.M. \& Zettelmeyer, F. (1999), "Brand Equity, Consumer Learning and Choice", Marketing Letters, Vol. 10, No. 3, p. 301.

Ewing, M., Pitt, L., de Bussy, N. \& Berthon, P. (2002), "Employment branding in the knowledge economy", International Journal of Advertising, Vol. 21, No. 1, pp. 3-22.

Franck, E., Pudack, T. \& Opitz, C. (2001), "Zur Funktion von Topmanagement-Beratungen als „Karrieresprungbrett“ für High Potentials", Working Paper No. 3 Lehrstuhl für Unternehmensführung und -politik Universität Zürich.

Glaser, B. \& Strauss, A. (1967), The Discovery of Grounded Theory, Chicago: Aldine.

Hanson, D., Dowling, P., Hitt, M., Ireland, R. \& Hoskisson, R. (2002), Strategic Management: Competitiveness and Globalization, Southbank.

Hoeffler, S. \& Keller, K.L. (2002), "Building brand equity through corporate societal marketing", Journal of Public Policy \& Marketing, Vol. 21, No. 1, p. 78.

Jain, S. \& Posavac, S. (2001), "Prepurchase Attribute Verifiability, Source Credibility, and Persuasion", Journal of Consumer Psychology, Vol. 11, No. 3, pp. 169-180.

Keller, K.L. (1993), "Conceptualizing, Measuring, Managing Customer-Based Brand Equity", Journal of Marketing, Vol. 57, No. 1, pp. 1-22.

Kirmani, A. \& Rao, A. (2000), "No pain, no gain: A critical review of the literature on signaling unobservable product quality", Journal of Marketing, Vol. 64, No. 2, pp. 6679.

Koku, P.S. (1995), "Price signaling: Does it ever work?" The Journal of Consumer Marketing, Vol. 12, No. 1, pp. 45-49.

Kotler, P. (1997), Marketing Management, Upper Saddle Hill: Prentice Hall.

Lee, T. (1999), Using Qualitative Methods in Organizational Research, Thousand Oaks: Sage Publications.

Martin, G., Beaumont, P., Doig, R. \& Pate, J. (2005), "Branding: A New Performance Discourse for HR?" European Management Journal, Vol. 23, No. 1, pp. 76-88.

Meffert, H., Burmann, C. \& Koers, M. (2002), Markenmanagement - Grundfragen der identitätsorientierten Markenführung, Wiesbaden: Gabler.

Miles, S. \& Mangold, G. 2004, "A Conzeptualization of the Employee Branding Process". In: M. Hartline \& D. Bejou (eds), Internal Relationship Management, Binghamton: Best Business Books. 
Mirrlees, J. (1971), "An Exploration in the Theory of Optimum Income Taxation", Rev. Econ Studies, Vol. 38, No. 2, pp. 175-208.

Mitchell, C. (2002), "Selling the Brand Inside", Harvard Business Review, Vol. 80, No. 1, pp. 99-105.

Papasolomou-Doukakis, I. (2003), "Internal Marketing in the UK Retail Banking Sector: Rhetoric or Reality?" Journal of Marketing Management, Vol. 19, No. 1/2, pp. 197224.

Park, C.W., Jaworski, B. \& Maclnnis, D. (1986), "Strategic Brand Concept-Image Management", Journal of Marketing, Vol. 50, No. 4, pp. 135-145.

Patton, M. (1990), Qualitative Evaluation and Research Methods, Thousand Oaks: Sage Publications Newbury Park.

Petkovic, M. (2004), "Geschickte Markenpolitik", Personal, Vol. 4, p. 6.

Rousseau, D. (2003), "Extending the psychology of the psychological contract: A reply to "putting psychology back into psychological contracts"', Journal of Management Inquiry, Vol. 12, No. 3, p. 229.

Rousseau, D. \& Greller, M. (1994), "Guest Editors' Overview: Psychological Contracts and Human Resource Practices", Human Resource Management (1986-1998), Vol. 33, No. 3, p. 383.

Rousseau, D.M. \& Wade-Benzoni, K.A. (1994), "Linking strategy and human resource practices: How employee and customer contracts are created", Human Resource Management, Vol. 33, No. 3, p. 463.

Sasser, W.E. \& Arbeit, S.P. (1976), "Selling Jobs in the Service Sector", Business Horizons, Vol. 19, No. 3.

Schmidtke, C. (2002), Signalling im Personalmarketing: Eine theoretische und empirische Analyse des betrieblichen Rekrutierungserfolges, München: Rainer Hamp Verlag.

Spence, A. (1973), "Job Marketing Signalling", Quarterly Journal of Economics, Vol. 87, No. 3, pp. 355-379.

Spence, M. (1974), Market Signaling: Informational Transfer in Hiring and Related Screening Processes, Cambridge: Harvard University Press.

Strauss, A. \& Corbin, J. (1998), Basics of Qualitative Research, Thousand Oaks: Sage Publications.

Sutherland, M.M., Torricelli, D.G. \& Karg, R.F. (2002), "Employer-of-choice branding for knowledge workers", South African Journal of Business Management, Vol. 33, No. 4, pp. 13-20.

Swait, J., Erdem, T., Louviere, J. \& Dubelaar, C. (1993), "The Equalization Price: A measure of consumer-perceived brand equity", International Journal of Research in Marketing, Vol. 10, pp. 23-45. 
Teufer, S. (1999), Bedeutung des Arbeitgeberimage bei der Arbeitgeberwahl, Wiesbaden: Deutscher Universitäts-Verlag

Thorne, K. (2004), One-Stop Guide: Employer Branding, Sutton.

Tirole, J. (1990), The Theory of Industrial Organization, Cambridge: MIT Press.

Tsao, H.-Y. 2002, 'An experimental study of brand signal quality of products in an asymmetric information environment', Curtin University of Technology, Perth.

Vickrey, W. (1961), "Counterspeculation, Auctions and Competitive Sealed Tenders", Journal of Finance, Vol. 16, No. 1, pp. 41-50.

Weiber, R. \& Adler, J. (1995), "Der Einsatz von Unsicherheitsreduktionsstrategien im Kaufprozess: Eine informationsoekonomische Analyse", Zeitschrift für betriebswirtschaftliche Forschung, Vol. Sonderheft 35, pp. 61-77. 